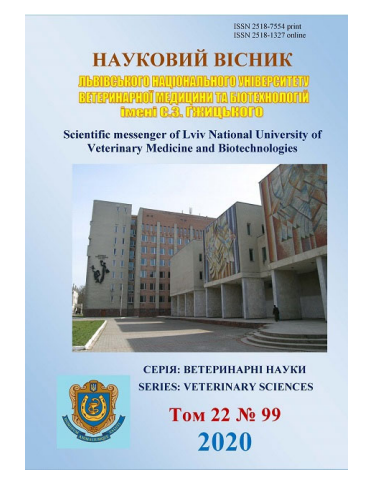

\author{
Науковий вісник Аьвівського національного університету \\ ветеринарної медицини та біотехнологій імені С.3. Гжицького. \\ Серія: Ветеринарні науки \\ Scientific Messenger of Lviv National University \\ of Veterinary Medicine and Biotechnologies. \\ Series: Veterinary sciences
}

\title{
Evaluation of usage of silicon-doped hydroxyapatite ceramics for treatment of fragmented bone fractures in dogs
}

\author{
M. V. Rublenko ${ }^{1}$, V. A. Chemerovskiy ${ }^{1}$, V. G. Andriiets ${ }^{1}$, N. V. Ulyanchich ${ }^{2}$, V. V. Kolomiets ${ }^{2}$, A. S. Koryak ${ }^{2}$ \\ ${ }^{1}$ Bila Tserkva National Agrarian University, Bila Tserkva, Ukraine \\ ${ }^{2}$ Institute for Problems in Material Science NASU, Kyiv, Ukraine
}

Article info

Received 02.09.2020

Received in revised form 30.09.2020

Accepted 01.10.2020

Bila Tserkva National Agrarian University, pl. 8/1 Soborna, Bila Tserkva, 09117, Ukraine. Tel.: +38-097-034-01-15 E-mail: valerii.chemerovskyi@btsau. edu.ua

Institute for Problems in Material Science NASU, Krzhizhanovsky Str., 3, Kyiv, 03142, Ukraine.
Rublenko, M. V., Chemerovskiy, V. A., Andriiets, V. G., Ulyanchich, N. V., Kolomiets, V. V., \& Koryak, A. S. (2020). Evaluation of usage of silicon-doped hydroxyapatite ceramics for treatment of fragmented bone fractures in dogs. Scientific Messenger of Lviv National University of Veterinary Medicine and Biotechnologies. Series: Veterinary sciences, 22(99), 29-37. doi: 10.32718/nvlvet9905

None of the methods of osteosynthesis provides the consolidation of bone fragments which have lost contact with soft tissues. It makes extremely difficult treating of this type fractures. Bone defect between the fragments and absence of a primary biological matrix complicates revascularization, causes long-term life of the connective tissue and cells of cartilaginous phenotype in the fracture zone. It is leads to a long-term consolidation of the fracture. Composites of hydroxyapatite and calcium phosphates are considered as bioactive and therefore the most promising for bone defects replacing. The aim of this investigation was clinical, radiological and hematological evaluation using of silicon-doped ceramics for fragmented bone fractures in dogs. For study was chosen dogs with accidental fragmented fractures of tubular bones which treated by extracortical osteosynthesis method. Animal was divided into two groups. A bone defects were filled with ceramics (GTlKg-3) for experimental animal group $(n=7)$, while no filling of bone defects in control animal group $(n=7)$ was performed. Protocol of anesthesia included medetomidine, butorphanol tartrate and epidural anesthesia with $2 \%$ lidocaine solution. Animals of the control group began to lean on the injured limb from the 12-15th day after surgery, while the animal of research group from the 8-9th day. Complete limb repair in dogs of the control group occurred on the 38-42th day, but such period for experimental group animals was shorter - 25-27th day after the osteosynthesis. X-ray investigation (60th day) of experimental group dogs showed new formed bone tissue with osteosclerotic zones without a periosteal reaction, bone tissue, with a normal view of the epiphyseal areas and the bone marrow cavity. This is evidence of localized reparative osteogenesis (within bone trauma only), and completed fracture consolidation. At the same time in cases of the control group we found lower X-ray density of new bone, periosteum was thickened with excessive proliferation of the endosteum, especially below the site of bone injury. Thus, in case the absence of hydroxyapatite matrix in bone defects there were compensatory increasing proliferation of periosteum and endoosteum. Fragmented fractures of tubular bones in dogs have occurred by erythrocytopenia, that quickly disappear due to the reparative osteogenesis in dog of experimental group. These animals have had leukocytosis increasing due to the first three days after osteosynthesis as a reaction to the implantation of a calcium-phosphorus composite material. Dogs of control group have had second wave of leukocytosis increasing on forty-second day associated with elongated remodeling process. Areparative osteogenesis can be accelerated in 1.5 times in case of replacement of bone defects with silicon doped hydroxyapatite ceramics. It is possibility realized thru moderate reduction of active phase of inflammation and acceleration of proliferative phase, mainly from endosteum side with early mineralization of bone regenerate. The dynamics of hematology parameters is a typical for the tubular bone consolidation that indicates about moderate inflammation and demonstrate biological tolerance of silicon-doped hydroxyapatite ceramics.

Key words: silicon-doped hydroxyapatite, ceramic, composite materials, osteosynthesis, bone fracture, erythrocytes, leukocytes, platelets, hemoglobin, dog. 


\title{
Клініко-рентгенологічна і гематологічна оцінка застосування кераміки, легованої кремнісм, за осколкових переломів кісток у собак
}

\author{
М. В. Рубленко ${ }^{1}$, В. О. Чемеровський ${ }^{1}$, В. Г. Андрієць ${ }^{1}$ Н. В. Ульянчич ${ }^{2}$ В. В. Коломієць ${ }^{2}$, О. С. Коряк² \\ ${ }^{1}$ Білочерківський національний аграрний й університет, Біла Церква, Украӥна \\ ${ }^{2}$ Інститут проблем матеріалознавства ім. І. Н. Францевича, м. Київ, Украӥна
}

\begin{abstract}
Ні один зі способів остеосинтезу не забезпечує консолідації осколкових фрагментів кістки, які втратили зв'язок з м'якими тканинами, щзо надзвичайно ускладнює лікування переломів такого типу. Внаслідок кісткового дефекту між уламками відсутність первинної біологічної матриці ускладнює реваскуляризацію, зумовлює тривале функціонування в зоні перелому сполучнотканинного і хрящсвого фенотипу клітин, щчо призводить до тривалої в часі консолідацї перелому. Композити гідроксиапатиту і фосфатів кальиію, вважаються біоактивними, а тому найбільш перспективними для замішення кісткових дефектів. Мета дослідження - клініко-рентгенологічна і гематологічна оиінка застосування кераміки, легованої кремнієм, за осколкових переломів кісток у собак. Сформували дослідну $(n=7)$ і контрольну $(n=7)$ групу собак із випадковими осколковими переломами довгих трубчастих кісток, у яких виконували екстракортикальний остеосинтез, а в дослідній кісткові дефекти заповнювали керамікою (ГТлК2-3). Анестезіологічне забезпечення включало внутрішньом'язове введення медитомідину, буторфанолу тартрат та епідуральну анестезію $2 \%$ розчином лідокаїну. Тварини контрольної групи починали опиратись на травмовану кіниівку із 12-15-ї доби, а дослідної-вже з 8-9-ї доби. Повне відновлення функиії кінцівки в контрольній групі відбувалося на 38-42-у, а в дослідній - на 2527-у добу після проведення остеосинтезу. На 60-ту добу в собак дослідної групи рентгенологічно досить чітко в діляниі кісткової травми візуалізувалася кісткова тканина з остеосклеротичними зонами без періостальної реакції з нормальною рентгенологічною картиною епіфізарних ділянок і кістковомозкової порожнини. Це було свідченням повної консолідації перелому та перебігом репаративного остеогенезу в межах лише кісткової травми. Натомість у контрольній групі на 60-у добу кістковий регенерат мав мениу рентгенологічну шільність, періост був потовщеним з надмірною проліферацією ендоосту, особливо нижче ділянки кісткової травми. Тобто за відсутності заміщення кісткових дефектів композитними імплантами відбувається компенсаторне посилення проліфераиії пері-та ендоосту. За осколкових переломів довгих трубчастих кісток у собак має місие помірна еритроиитопенія, яка досить швидко усувається в динаміці репаративного остеогенезу за використання в якості імплантів у кістковий дефект гідроксиапатитної кераміки, легованої кремнієм. У дослідних тварин в перші три доби після остеосинтезу лейкоиитоз посилюється як реакиія на імплантацію кальцій-фосфорного композитного матеріалу, а в контрольних його посилення на 42-у добу пов 'язане з процесами ремоделювання. У випадку замішення кісткових дефектів за осколкових переломів довгих трубчастих кісток у собак керамікою на основі гідроксиапатиту і $\beta$-трикальиійфосфату, легованої кремнієм, репаративний остеогенез прискорюється в 1,5 разу за рахунок скорочення його запально-резорбтивної стадї та прискорення проліферативної, головним чином з боку ендоосту з ранньою мінералізацією кісткового регенерату. Динаміка гематологічних показників є типовою для консолідаціі довгих трубчастих кісток у собак, щуо свідчить про відсутність вираженої реакції організму на імплантацію гідроксиапатитної кераміки, легованої кремнієм.
\end{abstract}

Ключові слова: гідроксиапатит, легований кремній, кераміка, композитні матеріали, остеосинтез, перелом кісток, еритроцүити, лейкоцитти, тромбоцчити, гемоглобін, собаки.

\section{Вступ}

Оптимізація репаративного остеогенезу, особливо за складних переломів кісток, є ключовою проблемою та завданням ветеринарної травматології і ортопедії. Зокрема, частка серед них осколкових переломів у дрібних домашніх тварин як за даними зарубіжних, так і вітчизняних дослідників, може складати 25-60\% від загальної кількості травм апарату руху (Nojiria et al., 2015; Rublenko et al., 2012). При цьому значна кількість переломів виникає внаслідок травм нанесених автотранспортом - 56-80 \%, менша частка - 1921,5 \% випадкових чи побутових травм і $3,7 \%-3$ причин недостатньо верифікованих власниками.

Під дією травмуючого чинника за осколкових переломів здебільшого відбувається порушення цілісності кісткового мозку, періосту, ендоосту та близьколежачих м'язових тканин із порушенням живлення пошкодженої ділянки за рахунок розриву чи розміжчення судинної сітки (Huminskyi \& Korenkov, 2009). Все це $\epsilon$ пусковим механізмом для розвитку гострої запальної реакції. Своєю чергою фаза запалення запускає як локальні, так і системні механізми забезпечення репаративної регенерації кісткової тканини (Dovhalevych, 2016). В перші хвилини після перелому активізуються фактори згортання крові, внаслідок чого у місці перелому тромбуються пошкоджені судини 3 подальшим формуванням фібринового згустка, який $є$ біологічною матрицею для подальших процесів проліферації кісткової тканини. Проте наявність кісткових дефектів за осколкових переломів суттєво ускладнює ці процеси у зв'язку з відсутністю кооптації їх уламків (Popsuishapka et al., 2015). Водночас ні один зі способів остеосинтезу не забезпечує консолідації осколкових фрагментів кістки, які втратили зв'язок з м'якими тканинами, що надзвичайно ускладнює лікування переломів такого типу.

Репаративна регенерація кісткової тканини - це складний молекулярно-біологічний і клітинний процес, за якого одночасно відбуваються процеси резорбції за рахунок остеокластів та синтезу і ремоделювання нової кісткової тканини за дії остеобластів 3 подальшою їі осифікацією та біологічною імплантацією в кістковий матрикс остеоцитів (Bumeister et al., 2008; Nutyny, 2015). За раціонального остеосинтезу травмована ділянка кістки відновлюється до ідентичної тканини, яка була до травми (Oryan et al., 2015; Hololobov, 2019). Наявність кісткових дефектів призводить до порушень спільного ендоостального і періостального живлення (Yurova et al., 2020) та відповідно до втрати регенеративного потенціалу кісткової тканини i, як наслідок, до незрощення, розвитку псев- 
досуглобів чи виникнення остеомієліту (Laurent et al., 2019; Nagi et al., 2020). Здебільшого у вітчизняній ветеринарній ортопедії застосовують методи інтрамедулярного, одно- чи двостороннього позавогнищевого остеосинтезу або ж комбінують інтрамедулярний 3 позавогнищевим (Rublenko et al., 2015). Проте за інтрамедулярного остеосинтезу осколкових переломів нерідко мають місце міграція штифтів, ротаційні рухи кісткових уламків, недостатня поздовжня підтримка, внаслідок чого виникає укорочення кінцівки, незрощення чи деформація кістки, періостити та ектопічна мінералізація м'яких тканин близько ділянки травми, а також остеомієліти (Priyanka et al., 2019). За використання апаратів зовнішньої фіксакції можливе інфікування місць імплантації шпиць, надмірна реакція м'яких тканин з утворенням спайок, остеомієліту, а також необхідний постійний антисептичний догляд за елементами конструкції (Luis et al., 2018). У будьякому разі внаслідок кісткового дефекту між уламками відсутність первинної біологічної матриці ускладнює реваскуляризацію, зумовлює тривале функціонування в зоні перелому сполучнотканинного і хрящового фенотипу клітин, що призводить до тривалої в часі консолідації перелому з низкою перерахованих ускладнень.

У зв'язку з вищезазначеним ключовим завданням в оптимізації репаративного остеогенезу за осколкових переломів $є$ остеопластика для заміщення і відновлення структурної цілісності та підвищення регенеративного потенціалу кісткової тканини. В регенеративній хірургії дефектів кісткової тканини виділяються (Shastov et al., 2019) такі основні напрями: вільна пластика, що передбачає застосування кісткових ауточи аллоімплантів, заміщення дефектів композитними матеріалами з різними остеотропними властивостями, невільну остеопластику на основі компресійнодистракційного остеосинтезу та їх комбінації.

Хоча використання аутоімплантів для заміщення кісткових дефектів все ще залишається “золотим стандартом”, проте вони мають низку суттєвих недоліків, таких як біоетичні проблеми, додаткова травма, достатньо високий ризик інфікування, складності в проведенні процедур одержання і зберігання, вікові аспекти тощо.

Композитні матеріали, які застосовуються під час лікування переломів 3 кістковими дефектами, повинні володіти остеокондуктивними, остеоіндуктивними, остеоінтеграційними та остеогенними властивостями (Reznik et al., 2018). Найбільшою мірою цим вимогам відповідають такі групи матеріалів: 1) біоорганічні демінералізований кістковий матрикс, колаген, фібринові композити; 2) керамічні матеріали - оксиди алюмінію та цирконію, гідроксиапатитні композити; 3) синтетичні полімери - поліметилметакрилат, полігліколід, полідіаксанон; 4) багатокомпонентні різних типів.

Оскільки основними неорганічними елементами кісткової тканини є гідроксиапатит і фосфати кальцію, то вони та їх композити вважаються біоактивними і найперспективнішими для заміщення кісткових дефектів (Talal et al., 2020). Наразі на ринку представ- лені зарубіжні та вітчизняні імплантаційні матеріали на основі гідроксиапатиту, $\beta$-трикальційфосфату чи $\alpha$ трикальційфосфату (Talashova et al., 2012; Huryn et al., 2012; Shumilovaa et al., 2014; Rahmati et al., 2018), які, однак, потребують суттєвого клінікоексперементального обгрунтування.

Зокрема, нами (Rublenko et al., 2018; Chemerovskiy, 2020) на модельних переломах у кролів було вивчено остеоінтеграційні властивості низки зразків гідроксиапатитної кераміки 3 різними фізико-хімічними характеристиками та визначено перспективність для клінічної апробації кераміки типу (ГТлКг-700, що являє собою відмиті двофазні гранули, леговані кремнієм, які складаються 370 \% гідроксиапатиту і 30 \% $\beta$-трикальційфосфату, витримані при температурі $850^{\circ} \mathrm{C}$ з розміром гранул 700 мкм).

Мета дослідження - клініко-рентгенологічна і гематологічна оцінка застосування кераміки, легованої кремнієм, за осколкових переломів кісток у собак.

\section{Матеріал і методи досліджень}

Дослідження виконували на собаках $(n=14)$ із випадковими осколковими переломами довгих трубчастих кісток, які надходили протягом 2018-2019 року до клініки дрібних домашніх тварин факультету ветеринарної медицини Білоцерківського НАУ. Найбільша частка цих переломів виникала внаслідок травм, нанесених автомобільним транспортом - 64 \% $(\mathrm{n}=9)$, меншу частку становили переломи, зумовлені травмуванням іншими тваринами - $22 \%(\mathrm{n}=3)$ і $14 \%$ $(\mathrm{n}=2)-3$ причин, недостатньо верифікованих власниками собак.

Дослідження проводились за згоди власників тварин та відповідно до Закону України "Про захист тварин від жорстокого поводження” від 28.03.2006 р № 27, ст. 230 і правил Свропейської конвенції захисту хребетних тварин, які використовуються в експериментальних та інших наукових цілях від 18.03.1986 р. № 994_137. та Наказу МОН № 416/20729 від 16 березня $20 \overline{1} 2$ р. "Про затвердження Порядку проведення науковими установами дослідів, експериментів на тваринах". Проект цих досліджень був схвалений Етичним комітетом Білоцерківського НАУ з питань поводження з тваринами у наукових дослідженнях та освітньому процесі (висновок № 2 від 31.05 .18 р., протокол № 1).

Травмованих тварин розділили на контрольну $(\mathrm{n}=7)$ та дослідну $(\mathrm{n}=7)$ групи. Діагноз на перелом встановлювали за клінічними ознаками та на підставі рентгенологічних досліджень, проведених на рентгенапараті РУМ-20. Отримані рентгензнімки відцифровували на електронний носій (AGFA. Healthcare N. V. CR 10-X, Німечинна).

За виконання остеосинтезу анестезіологічне забезпечення включало внутрішньом'язове введення медитомідину (20 мкг/кг, медісон, Бровафарма), буторфанолу тартрат (0,1 мг/кг), бутолар 300) та епідуральну анестезію $2 \%$ розчином лідокаїну (3 мг/кг). Для підтримання анестезії внутрішньовенно вводили розчин тіопенталу натрію (7 мг/кг, тіопенат, Бровафарма). 
Після проведення оперативного доступу до ділянки перелому видаляли осколки (рис. 1) і гравіметрично визначали об'єм кісткового дефекту шляхом заповнення його порожнини пластичною масою альгінату натрію, (порошок альгінату змішували із стерильним $0,9 \%$ розчином $\mathrm{NaCl}$ у співвідношенні $1: 2$ за температури $\left.23{ }^{\circ} \mathrm{C}\right)$. Після затвердіння його маси вилучали 3 дефекту та поміщали у мірний циліндр з водою. За об’ємом витісненої води встановлювали об'єм дефекту, який у тварин обох груп коливався у межах $1,9 \pm 0,05 \mathrm{~cm}^{3}$.

У контрольній і дослідній групах виконували екстракортикальний остеосинтез опорною пластиною із нелегованого титанового сплаву. У контрольній групі кісткові дефекти залишали загоюватись під кров'яним згустком, а у дослідній заміщували керамікою на основі гідроксиапатиту з 30 \% $\beta$-трикальційфосфату, легованого кремнієм (ГТлКг-3), виготовленого в Інституті матеріалознавства ім. I. Н. Францевича (м. Київ). Рани після встановлення дренажу із поліпропіленової трубки ушивали вузлуватим швом, а тваринам у післяопераційний період призначали курс антибіотикотерапії (цефтріаксон 10 мг/кг двічі на добу протягом 7 діб).

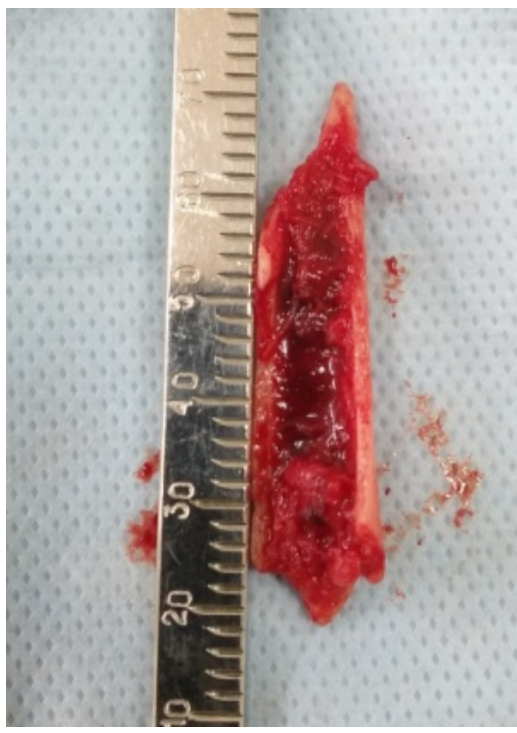

Видалений осколок кістки

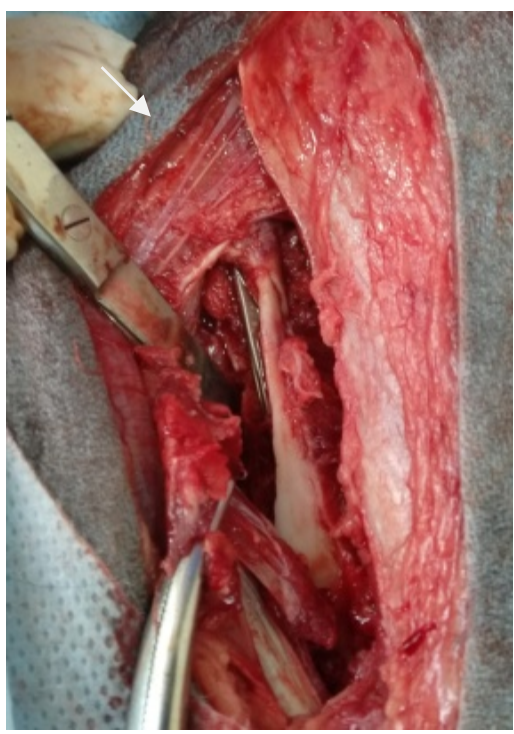

Кістковий дефект

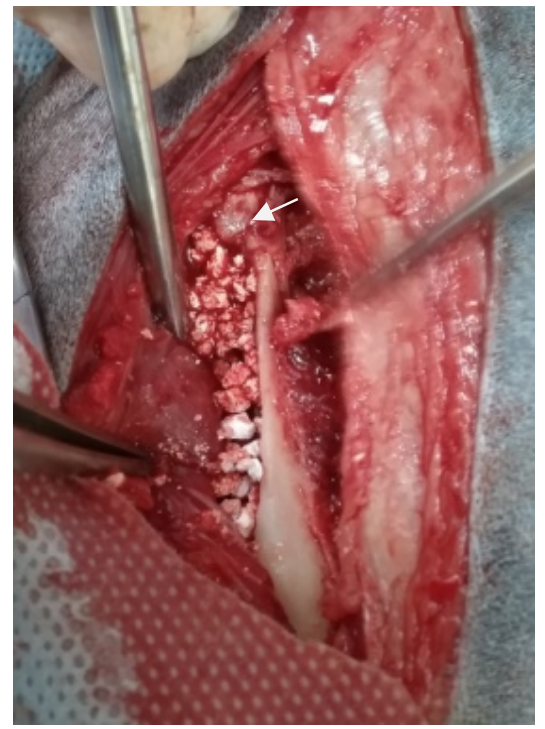

Заміщення дефекту ГТлКг-3

Рис. 1. Макроморфологічна картина етапів остеосинтезу і заміщення кісткового дефекту керамікою у дослідній групі

Проби крові відбирали після травми не пізніше 48ї доби, та на 3-, 12-, 21-, 42- та 60-у добу після остеосинтезу. Для підвищення об'єктивності гематологічного аналізу додатково сформували контрольну групу із клінічно здорових собак, які надходили в клініку дрібних домашніх тварин Білоцерківського НАУ для проведення планової вакцинації $(\mathrm{n}=10)$. В післяопераційний період клінічні дослідження проводили за критеріями загального стану тварин, терміном зникнення набряку і болючості, початку опирання та повного відновлення функцій травмованої кінцівки. Рентгенологічну оцінку репаративного остеосинтезу виконували на 42- та 60-у добу, гематологічне дослідження виконували загальноприйнятими методами, iз визначенням у крові еритроцитів, лейкоцитів, тромбоцитів та гемоглобіну - після травми та на 3-, 12-, 21-, 42- та 60-у добу. Статистичний аналіз отриманих результатів проводили за допомогою програми (StatPOLRoms).

\section{Результати дослідження}

Клінічні дослідження. Після остеосинтезу в тварин обох груп дія загальних анестетиків поступово припинялась через 30-40 хв. Через 4-7 годин тварини приймали природне положення тіла у просторі, проте не опиралися на травмовану кінцівку. На 1-у добу після операції в усіх тварин у ділянці операційної травми проявлялась помірна запальна реакція, яка супроводжувалася набряком тканин і місцевим підвищенням температури, виділенням серозного ексудату із нижньої частини дренажу. На 3-ю добу підвищення температури в ділянці травми не виявляли, через дренаж дещо просочувався серозний ексудат. На 4-у добу після оперативного втручання виділень серозного ексудату не спостерігали, після чого дренаж знімали.

На 7-9-у добу після операційного періоду набряк та болючість були відсутні, краї ран утримувалися сполучнотканинною спайкою в стані епітелізації, що є підставою для зняття швів. Тварини контрольної групи починали опиратись на травмовану кінцівку із $12-$ 15-ї доби, а дослідної - вже з 8-9-ї доби. Повне відновлення функції кінцівки у контрольній групі відбувалося на 38-42-у, а в дослідній - на 25-27-у добу після проведення остеосинтезу.

Рентгенологічні дослідження. На рентгенограмах після проведеного екстракортикального остеосинтезу 
і заміщення у дослідній групі кісткового дефекту керамікою констатували анатомічно точну репозицію проксимальних і дистальних ділянок стегнової кістки
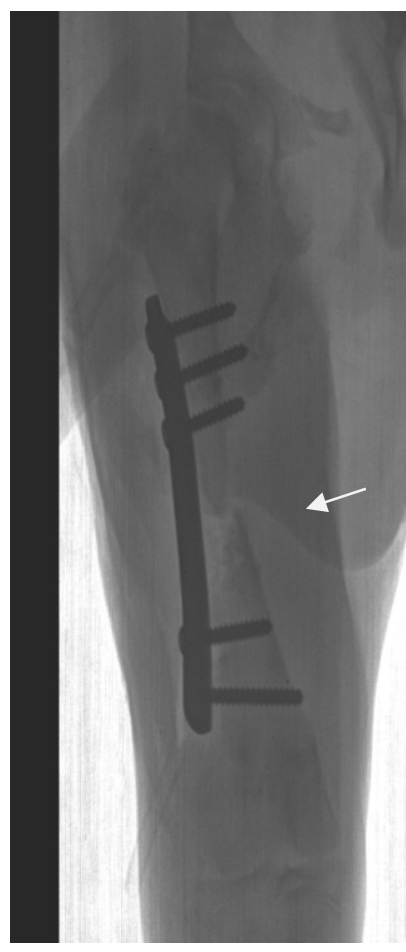

А) дослідна iз максимально кооптованими краями перелому один до одного (рис. 2). В дослідній групі у місці дефекту виявляли наявність гранул керамічного композиту.

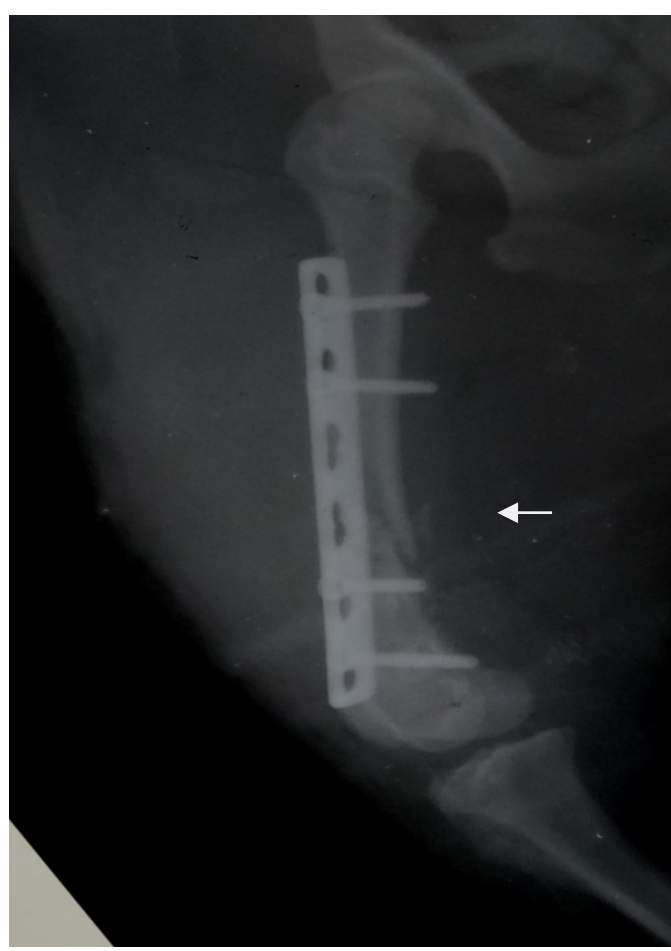

Б) контрольна

Рис. 2. Рентгенограми стегнової кістки собаки після остеосинтезу: А - дослідна; Б - контрольна групи

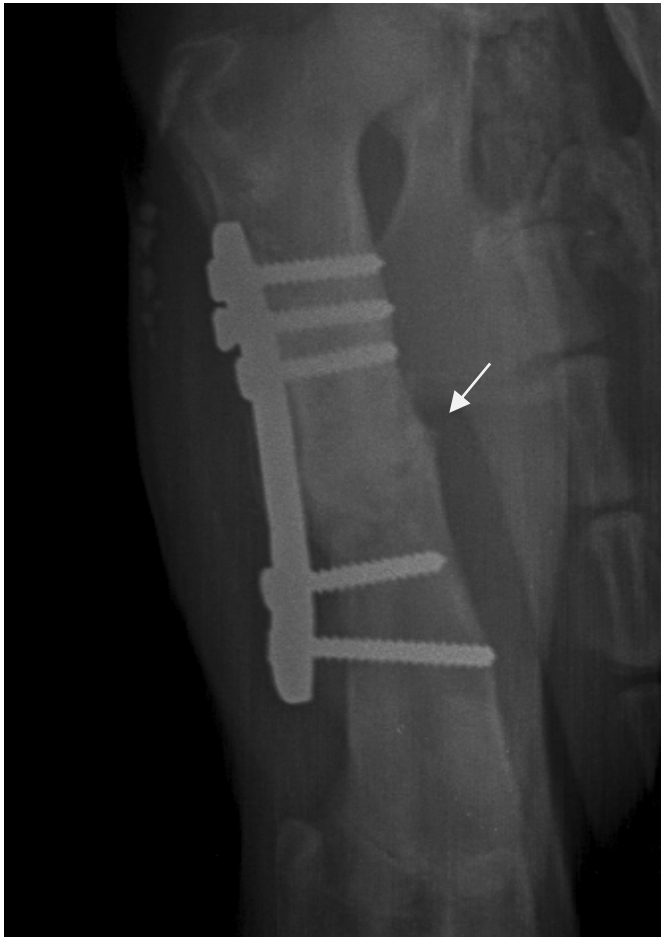

А) дослідна

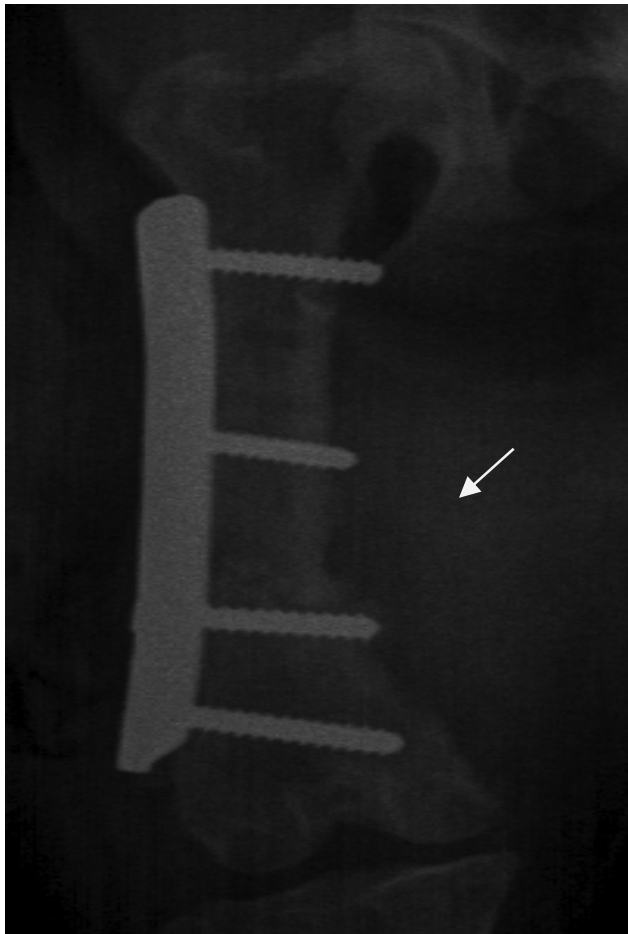

Б) контрольна

Рис. 3. Рентгенограми стегнової кістки собаки на 42-у добу після остеосинтезу:

$$
\text { А - дослідна; Б - контрольна групи }
$$

Рентгенологічно на 42-у добу (рис. 3) після остеосинтезу в дослідній групі кістковий дефект був виповнений кістковим регенератом досить високої щіль- ності з помірною періостальною реакцією в межах кісткової травми. 
Водночас у контрольній групі в цей період кістковий регенерат мав вигляд неоднорідного, різної щільності утворення, проксимально і дистально від якого кісткова тканина характеризувалась явищами плямистого остеопорозу з яскраво вираженою грубо структурованою періостальною реакцією, особливо дистально від місця перелому. Тобто в цей період досліджень у собак контрольної групи мали місце досить виражені запально-резорбтивні процеси.

На 60-у добу (рис. 4) в собак дослідної групи рентгенологічно досить чітко в ділянці кісткової травми візуалізувалися кісткова тканина $з$ остеосклеротични-

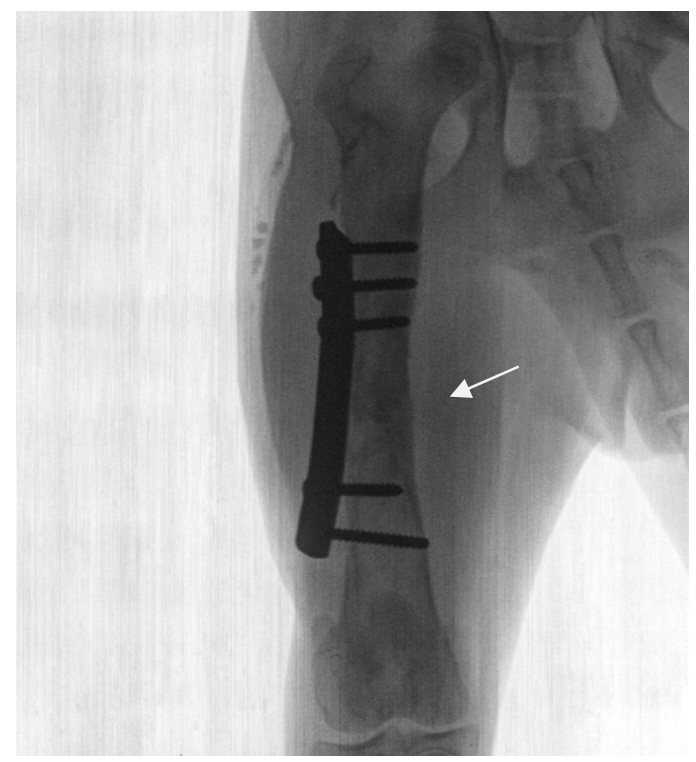

А) дослідна ми зонами без періостальної реакції, 3 нормальною рентгенологічною картиною епіфізарних ділянок $\mathrm{i}$ кістковомозкової порожнини. Це було свідченням повної консолідації перелому та перебігом репаративного остеогенезу в межах лише кісткової травми. Натомість у контрольній групі на 60-у добу кістковий регенерат мав меншу рентгенологічну щільність, періост був потовщеним 3 надмірною проліферацією ендоосту, особливо нижче ділянки кісткової травми. Тобто за відсутності заміщення кісткових дефектів композитними імплантами відбувається компенсаторне посилення проліферація пері-та ендоосту.

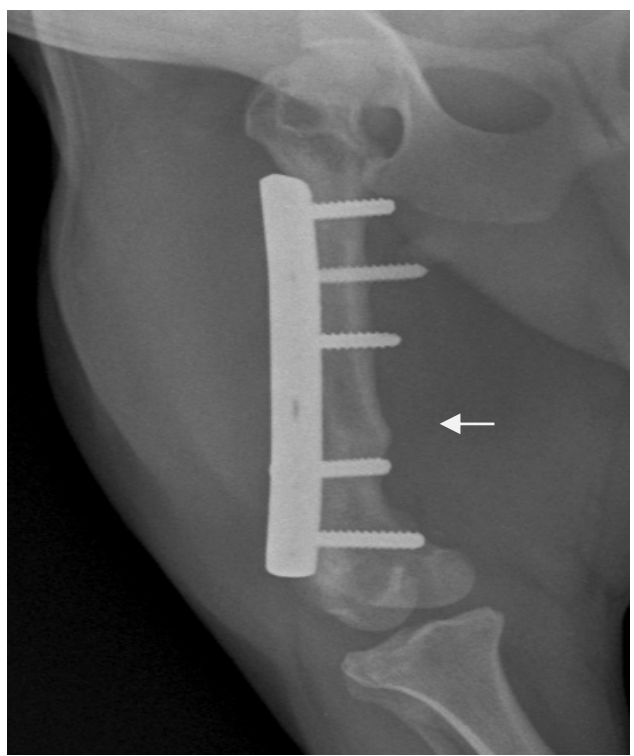

Б) контрольна

Рис. 4. Рентгенограми стегнової кістки собаки на 60-у добу після остеосинтезу: А - дослідна; Б - контрольна група

Гематологічні дослідження. У собак із осколковими переломами довгих трубчастих кісток у перші 48 годин після виникнення перелому виявляли (табл. 1) зменшення в 1,2 разу $(\mathrm{P}<0,001)$ кількості еритроцитів після травми порівняно із показником клінічно здорових тварин. Дещо в меншій мірі - в 1,1 разу $(\mathrm{P}<0,05)$ виявилась зниженою кількість гемоглобіну. При цьому вміст у крові тромбоцитів зменшився не вірогідно, а кількість лейкоцитів збільшилась в 1,3 разу $(\mathrm{P}<0,01)$ порівняно 3 клінічно здоровими тваринами. Такі гематологічні зміни насамперед пов'язані з крововиливом у ділянці перелому, який у випадку травм довгих трубчастих кісток досить великий за об'ємом. Також виникає гостра запальна реакція, про що свідчить збільшення кількості лейкоцитів.

За аналізу кількості еритроцитів у крові собак в динаміці репаративного остеогенезу виявили такі зміни: в дослідній групі на 3-ю добу вона залишилася на попередньому рівні, а у контрольній спостерігали суттєву тенденцію до іiі зниження. У контрольних тварин низькі показники кількості еритроцитів утримувалася аж до 42-ї доби, тимчасом як у дослідних їх відновлення до меж фізіологічної норми відбулося вже на 12-у добу.
Дещо подібною виявилась і динаміка вмісту в крові гемоглобіну, проте всі його зміни відбувалися у межах фізіологічної норми. При цьому в період 3-ої та 42-ої доби його рівень у тварин дослідної групи вірогідно був вищим - у 1,1 разу $(\mathrm{P}<0,05-0,01)$. Тобто за осколкових переломів довгих трубчастих кісток у собак має місце помірна еритроцитопенія, яка досить швидко усувається в динаміці репаративного остеогенезу за використання в якості імплантів у кістковий дефект гідроксиапатитної кераміки, легованої кремні$\epsilon \mathrm{M}$.

Хоча в цілому лейкоцитарна реакція в процесах консолідації переломів відбувалася в межах показників фізіологічної норми, проте перші три доби вона все ж таки мала ознаки помірного патофізіологічного лейкоцитозу, більш тривалого, із двома піками, у контрольних тварин. Зокрема, після травмування кісток кількість лейкоцитів у крові собак збільшувалась в 1,3 разу $(\mathrm{P}<0,01)$. На 3 -ю добу після остеосинтезу в дослідних тварин вона досягала рівня $13,4 \pm 0,6$ Г/л, що було більше в 1,3 разу $(\mathrm{P}<0,01)$, ніж у контрольних. Надалі цей показник у перших динамічно зменшився і коливався в межах фізіологічної норми, а у других - мав ще один пік лейкоцитарної реакції на 42-у добу $-11,5 \pm 0,5$ Г/л. Тобто в до- 
слідних тварин у перші три доби після остеосинтезу лейкоцитоз посилюється як реакція на імплантацію кальцій-фосфорного композитного матеріалу, а в контрольних свідчить про його посилення у зв'язку 3 процесами ремоделювання.
Тромбоцитарна реакція також мала фізіологічний характер, а більша кількість тромбоцитів в 1,2 разу $(\mathrm{P}<0,05)$ в дослідних тварин у період 12-ої доби спонукає до думки про дещо ефективнішу реалізацію у них тромбоцитарних факторів росту в репаративному остеогенезі.

Таблиця 1

Динаміка гематологічних показників за репаративного остеогенезу у собак

\begin{tabular}{|c|c|c|c|c|c|c|}
\hline \multirow{3}{*}{$\begin{array}{c}\text { Терміни } \\
\text { дослі- } \\
\text { дження, } \\
\text { доба }\end{array}$} & & Показники & $\begin{array}{c}\text { Еритроцити, Т/л } \\
(5-8,5)\end{array}$ & $\begin{array}{c}\text { Гемоглобін, г/л } \\
(110-170)\end{array}$ & $\begin{array}{c}\text { Лейкоцити, Г/л } \\
(8,5-10,5)\end{array}$ & $\begin{array}{c}\text { Тромбоцити, Г/л } \\
(250-550)\end{array}$ \\
\hline & & лінічно здорові $(\mathrm{n}=10)$ & $5,7 \pm 0,08$ & $136,4 \pm 1,3$ & $8,5 \pm 0,21$ & $298 \pm 15,8$ \\
\hline & & Після травми $(\mathrm{n}=14)$ & $4,7 \pm 0,16$ & $126,4 \pm 4,0$ & $11,4 \pm 0,76$ & $287,3 \pm 15,3$ \\
\hline \multirow{2}{*}{$3-я$} & \multirow{10}{*}{ 胥 } & $\underline{I}$ & $\underline{4,5 \pm 0,3}$ & $\underline{126,9 \pm 3,3^{*}}$ & $13,4 \pm 0,6^{* *}$ & $317,2 \pm 20,3$ \\
\hline & & II & $\overline{4,2 \pm 0,19}$ & $112,5 \pm 4,8$ & $10,5 \pm 0,6$ & $\overline{277,4 \pm 20,8}$ \\
\hline \multirow{2}{*}{$12-\mathrm{a}$} & & $\underline{I}$ & $\underline{5,1 \pm 0,1 * *}$ & $132,7 \pm 6,0$ & $11,4 \pm 0,7$ & $271,2 \pm 9,1^{*}$ \\
\hline & & II & $4,3 \pm 0,2$ & $\overline{124,2 \pm 5,1}$ & $11,6 \pm 0,4$ & $231,2 \pm 9,6$ \\
\hline \multirow{2}{*}{$21-\mathrm{a}$} & & $\underline{I}$ & $4,7 \pm 0,1$ & $128,6 \pm 2,8$ & $\underline{10,1 \pm 0,6}$ & $268 \pm 5,5$ \\
\hline & & $\overline{\text { II }}$ & $\overline{4,6 \pm 0,1}$ & $\overline{123,5 \pm 1,2}$ & $\overline{10,2 \pm 0,4}$ & $\overline{272,4 \pm 14,7}$ \\
\hline \multirow{2}{*}{$42-\mathrm{a}$} & & $\underline{I}$ & $5,2 \pm 0,08 * *$ & $153,2 \pm 3,9^{* *}$ & $9,7 \pm 0,2 * *$ & $293,8 \pm 5,4$ \\
\hline & & $\overline{\mathrm{II}}$ & $4,7 \pm 0,1$ & $136,5 \pm 1,9$ & $11,5 \pm 0,5^{*}$ & $\overline{291,5 \pm 16,6}$ \\
\hline \multirow{2}{*}{$60-a$} & & $\underline{I}$ & $5,5 \pm 0,1 * * *$ & $136,4 \pm 7,5$ & $10,1 \pm 0,4^{*}$ & $260,7 \pm 5,5$ \\
\hline & & II & $4,9 \pm 0,08$ & $\overline{144,5 \pm 4,0}$ & $9,4 \pm 0,2$ & $\overline{259,7 \pm 9,4}$ \\
\hline
\end{tabular}

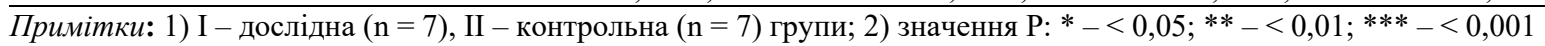

\section{Обговорення}

Репаративний остеогенез у разі складних осколкових переломів із дефектами кісткової тканини після того чи іншого методу остеосинтезу відбувається за вторинним типом загоєння. Проте навіть за незначних дефектів його стадії подовжуються залежно від ступеня порушення ендоостального чи періостального живлення, а відповідно і втрати репаративного потенціалу кісткової тканини. У зв'язку з цим насамперед переломи такого типу, крім використання раціональних біомеханічно обгрунтованих способів і засобів остеосинтезу, потребують застосування лікувальних принципів регенеративної медицини.

Незважаючи на здатність низки біологічних матеріалів (ембріональна кісткова тканина, мезенхімальні стовбурові клітини, тромбоцитарні концентрати i кісткові морфогенетичні білки) відновлювати регенеративний потенціал кісткової тканини (Bulatov et al., 2005; Yongseok et al., 2018; Blazhenko et al., 2019), вони потребують наявності матриці - носія з остеокондуктивними властивостями і оптимальними біомеханічними характеристиками. Своєю чергою композитні матеріали, які імплантують у місці кісткового дефекту, також повинні мати властивості індукувати процеси ангіогенезу, що сприяло б утворенню судинної сітки у місці перелому і відновленню живлення.

Кераміка на основі гідроксиапатиту i ßтрикальційфосфату, яка попередньо була апробована нами (Rublenko et al., 2015) в серії експериментів і на клінічному матеріалі, володіє вираженими остеокондуктивними та остеоінтеграційними властивостями, але не остеоіндуктивними. Останніх можна досягти за рахунок легування композиту такими мікроелементами, як Магній, Цинк, Мідь, Кремній, Германій (Neill et al., 2018). Серед них перспективним вважається
Кремній, оскільки він фізіологічно пришвидшує процеси остеогенезу за рахунок його участі в індукції активного росту остеобластів, в синтезі кісткового колагену, незалежного від вітаміну Д, та кристалізації гідроксиапатиту (Kartel et al., 2015).

При цьому клініко-рентгенологічні дослідження верифікують динамічність процесів консолідації переломів кісток з дефектами, що виражається у скороченні запально-резорбтивної стадії репаративного остеогенезу із залученням в нього меншого об'єму кісткової тканини за межами травми, переважному формуванні кісткового регенерату за рахунок ендоостального остеогенезу та ранньої його мінералізації. При цьому, зважаючи на результати попередніх досліджень (Smurna, 2009) щодо імплантації гідроксиапатитної кераміки за осколкових переломів у собак, можна констатувати, що включення до неї іонів Кремнію, надає їй остеоіндуктивних властивостей. Поряд 3 цим апробований керамічний композит не зумовлює реактивних змін в організмі, про що свідчать результати гематологічних досліджень, а наявні зміни картини крові є типовими для травм кісток і процесу їх консолідації у собак, що узгоджується з даними попередніх дослідників (Pustovit, 2008; Rublenko et al., 2013).

\section{Висновки}

1. У випадку заміщення кісткових дефектів за осколкових переломів трубчастих кісток у собак керамікою на основі гідроксиапатиту i $\beta$ трикальційфосфату, легованої кремнієм, репаративний остеогенез прискорюється в 1,5 разу за рахунок скорочення його запально-резорбтивної стадії та прискорення проліферативної, головним чином з боку 
ендоосту 3 ранньою мінералізацією кісткового регенерату.

2. Динаміка гематологічних показників є типовою для консолідації довгих трубчастих кісток у собак, що свідчить про відсутність вираженої реакції організму на імплантацію гідроксиапатитної кераміки, легованої кремнієм.

3. Кераміка ГТлКг-3 є перспективним композитним матеріалом за лікування складних осколкових переломів у собак 3 можливістю більш широкого використання після молекулярно-біологічного і гістоморфологічного обгрунтування.

\section{References}

Nojiria, A., Nishidoa, T., Horinakaa, O., Akiyoshib, H., Ohashib, F., \& Yamaguchia, T. (2015). Initial Clinical Application and Results of the Advanced Locking Plate System (ALPS) in Small Animal Orthopedics: Two Hundred Eighty Two Procedures. Intern J Appl Res Vet Med, 13(1), 64-79. URL: https://www.jarvm.com/articles/Vol14Iss1/Vol14\%20 Iss1Nojiri.pdf.

Rublenko, S. V., \& Yeroshenko O. V. (2012). Monitorynh veterynarnoi dopomohy i struktura khirurhichnoi patolohii sered dribnykh domashnikh tvaryn $\mathrm{v}$ umovakh miskoi kliniky. Visnyk Sumskoho NAU, 1(30), 150-154 (in Ukrainian).

Huminskyi, Yu. I., \& Korenkov, O. V. (2009). Suchasni aspekty ekomorfolohii reparatyvnoho osteoheneza. Visnyk Sumskoho derzhavnoho universytetu, 2(1), 17-23 (in Russian).

Dovhalevych, Y. Y. (2016). Narushenye reparatyvnoho osteoheneza pry ynfytsyrovannokh defektakh trubchatukh kostei. Repozytoryi BHMU, 4, 76-80 (in Russian).

Popsuishapka, O. K., Litvishko, O. V., \& Ashukina, N. O. (2015). Kliniko-morfolohichni stadii protsesu zroshchennia vidlamkiv kistky. Ortopedyia, travmatolohyia y protezyrovanye, 1, 12-20. doi: 10.15674/0030-59872015112-20 (in Russian).

Bumeister, V. I., \& Pohorielov, M. V. (2008). Suchasnyi pohliad na reparatyvnyi osteohenez. Svit medytsyny ta biolohii, 4, 104-110. (in Ukrainian).

Nutyny, A. (2015). Teoretycheskaia model perestroiky kostnoi tkany. Rossyiskyi zhurnal byomekhanyky, 19(4), 385-397. doi: 10.15593/RZhBiomeh/2015.4.05 (in Russian).

Oryan, A., Monazzah, S., \& Bigham-Sadegh, A. (2015). Bone Injury and Fracture Healing Biology. Biomed Environ Sci, 28(1), 57-71. doi: 10.3967/bes2015.006.

Hololobov, V. H. (2019). Reheneratsionnyj endoossalnyj osteohistohenez kak sostavliaiushchyi protsess posttravmatycheskoi osteoreparatsyia. Hystohenez y reheneratsyia tkanei, 3, 105-107 (in Russian).

Yurova, K. A., Khazyakhmatova, O. H., Malashchenko, V. V., Norkyn, Y. K., Yvanov, P. A. ta in. (2020). Cellularmolecular aspects of inflammation, angiogenesis and osteogenesis. A short review. Tsytolohyia, 62(5), 305315. doi: 10.31857/S0041377120050090 (in Russian).
Nagi, A. M., Hassan, E. A., Al-Mokaddem, A. K., Azeem, A. E., \& Hamid1, A. A. (2020). Osteogenic Potential of 3-D printed Multilayered Poly L-lactic Acid (PLLA) Scaffold on the Healing of Critical-sized Bone Defect in Dogs. Int J Vet Sci, 1, 20-26. doi: 10.37422/IJVS/039.

Laurent, P. G., Reunan, P. G., \& Loic M. D. (2019). Minimally invasive percutaneous medial plate rod osteosynthesis for treatment of bicondylar humeral fractures in dogs: Surgical technique and case rep ort. Veterinary Surgery, 48, O34-O40. doi: 10.1111/vsu.13196.

Priyanka, T. S., Mohindroo, J., Pallavi, V., Udheiya, R., \& Umeshwori, N. (2019). Evaluation of intramedullary pinning technique for management of tibia fractures in dogs. The Pharma Innovation Journal, 8(2), 291-297. URL: http://www.thepharmajournal.com/archives /2019/ vol8issue2/PartE/8-2-24-179.pdf.

Luis, G. G. G. D., João, G. P. F., Maria, E. B. A. M. C., Fernanda, G. G. D., \& Virginia, T. B. (2018). Description and post-operative evaluation of tie-in technique in tibial osteosynthesis in dogs. Pesq. Vet. Bras, 38(7), 1376-1381. doi: 10.1590/1678-5150-PVB-5543.

Shastov, A. L., Kononovych, N. A., \& Horbach, E. N. (2018). Problema zameshhenija posttravmaticheskih defektov dlinnyh kostej $\mathrm{v}$ otechestvennoj travmatologo-ortopedicheskoj praktike (obzor literatury). Genij Ortopedii, 24(2), 252-257. doi: 10.18019/10284427-2018-24-2-252-257 (in Russian).

Reznik, L. B., Erofeev, S. A., Stasenko, I. V., \& Borzunov, D. Yu. (2019). Morphological assessment of osteointegration of various implants for management of long bone defects (experimental study). Genij Ortopedii, 25(3), 318-323. doi: 10.18019/1028-44272019-25-3-318-323.

Talal, A., Hamid, S. K., Khan, M., Khan, A. S., Dentistry, C. et al. (2020). Structure of biological apatite: bone and tooth.1 Handbook of Ionic Substituted Hydroxyapatites, 1, 1-20. doi: 10.1016/B978-0-08-1028346.00001-X.

Rahmati, M., Pennisi, C. P., Budd, E., Mobasheri, A., \& Mozafari, M. (2018). Biomaterials for Regenerative Medicine: Historical Perspectives and Current. Adv Exp Med Biol - Cell Biology and Translational Medicine, 4, 1-19. doi: 10.1007/5584_2018_278.

Talashova, Y. A., Sylanteva, T. A., Kononovych, N. A., \& Luneva, S. N. (2012). Otsenka byosovmestymosty implantatsionnykh kaltsij-fosfatnykh materialov $\mathrm{v}$ zavisimosti ot ikh mineralnoho sostava. Biulleten sibirskoi medytsyny, 3, 62-69 (in Russian).

Shumilovaa, A. A., \& Shishatskayaa, E. I. (2014). Materials for Restoration of Bone Tissue. Journal of Siberian Federal University. Biology, 7, 209-221. URL: http://elib.sfu-kras.ru/handle/2311/13407.

Huryn, A. N., Komlev, V. S., Fadeeva, Y. V., Petrakova, N. V., \& Varda, N. S. (2012). Sravnitelnoje issledovanije zameshchenija defektov kostnoj tkani osteoplasticheskimi materialami na osnove $\alpha$ - y $\beta$-trykaltsyifosfata. Stomatolohija, 6, 16-21 (in Russian).

Chemerovskyi, V. O. (2020). Renthenohrafichna, makromorfolohichna i hematolohichna otsinka hidroksyapatytnoi keramiky $\mathrm{z}$ riznymy fizyko- 
khimichnymy vlastyvostiamy. Naukovyi visnyk veterynarnoi medytsyny, 1, 140-152. doi: 10.33245/23104902-2020-154-1-140-152 (in Ukrainian).

Rublenko, M. V., Chemerovskyi, V. O., Vlasenko, V. M., \& Ulianchych, N. V. (2018). Otsinka osteointehratsiinykh i osteoinduktyvnykh vlastyvostei keramiky, lehovanoi kremniiem, za modelnykh perelomiv stehnovoi kistky u kroliv. Naukovyi visnyk BNAU, 2, $37-$ 46. doi: 10.33245/2310-4902-2018-144-2-37-46 (in Ukrainian),

Blazhenko, A. N., Rodyn, Y. A., Ponkyna, O. N., Mukhanov, M. L., \& Samoilova, A. S. (2019). Vlijanie APRP terapii na reparativnye regenerattivnoj kostnoj tkani pri svezhih perelomah kostej konechnostej. Innovacionnaja medicina Kubani. Innovatsionnaya meditsina Kubani, 15, 32-38. doi: 10.35401/2500-02682019-15-3-32-38 (in Russian).

Yongseok, Y., Imdad, U. K., Kyeong, U. C., Taeseong, J., Kwangrae, J., et al. (2018). Different Bone Healing Effects of Undifferentiated and Osteogenic Differentiated Mesenchymal Stromal Cell Sheets in Canine Radial Fracture Model. Tissue Eng Regen Med, 15(1), 115-124. doi: 10.1007/s13770-017-0092-8.

Bulatov, A. A., Saveleva, Y. V., \& Kalynyn, A. V. (2005). Primenenie kostnyh morfogeneticheskih belkov $\mathrm{v}$ jeksperymente i klinike.Travmatologija i ortopedija rossii, 1(34), 46-54 (in Russian).

Rublenko, M. V., Dudka, V. B., \& Semeniak, S. A. (2015). Morfo-renthenolohichna i biokhimichna kharakterystyky reparatyvnoho osteohenezu za zamishchennia kistkovykh defektiv biominom HT u tvaryn. Naukovyi visnyk veterynarnoi medytsyny, 1, 98-106 (in Ukrainian).

Neill, O. E., Awale, G., Daneshmandi, L., Obum, U., \& Kevin, L. (2018). The roles of ions on bone regeneration. Drug Discovery Today, 23(4), 279-290. doi: 10.1016/j.drudis.2018.01.049.

Kartel, M., Zhukovtseva, O., Malanchuk, V., Kiselov, V., Aleksyeyeva, T., \& Wang, B. (2015). Nanocomposite based on $\mathrm{SiC} / \mathrm{Si}$ : a new biomorphic material for maxillofacial surgery (experimental studiens), Poverhnost', 7(22), 311-316. URL: http://dspace.nbuv.gov.ua/ handle/123456789/148501.

Rublenko, M. V., Andriiets, V. H., Semeniak, S. A., Ulianchych, N. V. ta in. (2015). Vykorystannia kompozytnykh materialiv za perelomiv trubchastykh kistok u tvaryn. Bila Tserkva (in Ukrainian).

Smurna, O. V. (2009). Zastosuvannia ekstrakortykalnoho osteosyntezu ta hidroksylapatytu "kerhap" pry perelomakh klubovoi kistky u sobak: avtoref. dys. na zdobuttia nauk. stupenia kand. vet. nauk: spets. 16.00.05 "Veterynarna khirurhiia". Bila Tserkva (in Ukrainian).

Rublenko, M. V., Yeroshenko, O. V. (2013). Hematolohichni ta biokhimichni aspekty farmakolohichnoi optymizatsii reparatyvnoho osteohenezu traneksamovoiu kyslotoiu ta atselizynom. Veterynarna medytsyna, 97, 346-349 (in Ukrainian).

Pustovit, R. V. (2008). Hemostaz ta yoho korektsiia pry perelomakh trubchastykh kistok u sobak: avtoref. dys. na zdobuttia nauk. stupenia kand. vet. nauk: spets. 16.00.05 "Veterynarna khirurhiia" Bila Tserkva (in Ukrainian). 